University of Nebraska - Lincoln

DigitalCommons@University of Nebraska - Lincoln

Short- and full-season soybean in stale seedbeds versus rolledcrimped winter rye mulch

Frank Forcella

USDA-ARS, Frank.Forcella@ars.usda.gov

Follow this and additional works at: https://digitalcommons.unl.edu/usdaarsfacpub

Forcella, Frank, "Short- and full-season soybean in stale seedbeds versus rolled-crimped winter rye mulch" (2013). Publications from USDA-ARS / UNL Faculty. 1488.

https://digitalcommons.unl.edu/usdaarsfacpub/1488

This Article is brought to you for free and open access by the U.S. Department of Agriculture: Agricultural Research Service, Lincoln, Nebraska at DigitalCommons@University of Nebraska - Lincoln. It has been accepted for inclusion in Publications from USDA-ARS / UNL Faculty by an authorized administrator of DigitalCommons@University of Nebraska - Lincoln. 


\title{
Short- and full-season soybean in stale seedbeds versus rolled-crimped winter rye mulch
}

\author{
Frank Forcella* \\ North Central Soil Conservation Research Laboratory, USDA-ARS, 803 lowa Avenue, Morris, MN, USA. \\ *Corresponding author: frank.forcella@ars.usda.gov
}

\begin{abstract}
Stale seedbeds are used by organic growers to reduce weed populations prior to crop planting. Rye mulches, derived from mechanically killed (rolled and crimped) winter rye cover crops, can serve the same purpose for spring-planted organic crops. Both methods can also be employed by conventional growers who face looming problems with herbicide resistant weeds. The objective of this research was to compare these methods over 2 years in central Minnesota in terms of weed seedling emergence, populations, biomass and manual-weeding times, as well as stands and yields of short-season and full-season soybean varieties planted late, in mid June. Rye mulch greatly lowered both pre- and post-planting weed populations of common annual weeds, which substantially affected necessity for augmented weed control. For instance, the need for within-crop manual-weeding was low for soybean planted into rye mulch $\left(0-6 \mathrm{~h} \mathrm{ha}^{-1}\right)$, but ranged from 15 to $66 \mathrm{~h} \mathrm{ha}^{-1}$ of labor for soybean planted in stale seedbeds and augmented by inter-row cultivation. However, rye mulch lowered soybean yield potential by $800-1000 \mathrm{~kg} \mathrm{ha}^{-1}$ compared with stale seedbeds in 1 of 2 years. With organic feedgrade soybean seed valued at $\$ 1 \mathrm{~kg}^{-1}$, conventional soybean seed at $\$ 0.5 \mathrm{~kg}^{-1}$, and labor for manual-weeding at $\$ 10 \mathrm{~h}^{-1}$, the use of rye mulch compared with stale seedbeds augmented by manual-weeding are equally rational choices for organic growers in central Minnesota (assuming labor is available for hand-weeding), but rye mulches probably would be a wise financial option for conventional growers compared with hand-weeding. Lastly, full-season soybean had higher yields than short-season soybean and probably represents a prudent selection in central Minnesota, regardless of the late planting date requirements for both the rye mulch and stale seedbed systems.
\end{abstract}

Key words: cover crop, false seedbed, hand-weeding, late planting, organic, weed control

\section{Introduction}

Management of arable weeds without the assistance of modern synthetic herbicides is difficult, but sometimes necessary. For instance, where weeds have evolved resistance to herbicides, periodic interjection of nonchemical methods of weed management may be indispensable for sustaining cropping systems otherwise wholly dependent upon herbicides ${ }^{1}$. In addition, non-chemical methods are compulsory for organic systems. Moreover, weed control is the major agronomic concern of most organic growers ${ }^{2,3}$.

Organic growers employ a wide range of methods to manage weeds ${ }^{4,5}$. Among the many methods are two 'pre-emergence' weed control tactics that can be used for spring-planted crops: stale (or false) seedbed technique and winter cover crops. Stale seedbeds are a longestablished practice that can be used with supplemental herbicides in conventional systems ${ }^{6}$ or without them in organic systems ${ }^{4}$. For example, spring weed populations emerging in previously cultivated soil are killed through subsequent cultivations prior to crop sowing. The stale seedbed could be prepared weeks or even months ahead of time (e.g., the previous autumn) to encourage the spring flush of weeds prior to actual crop planting. Weed control typically improves appreciably with later cultivations in spring, but subsequent crop yield tends to decline with these late planting dates ${ }^{7}$. Thus, a balance must be reached between low weed populations and high crop yield in terms of successful application of the stale seedbed technique ${ }^{8}$. Additional issues with stale seedbed management are that repeated soil cultivations cause commensurate losses in arbuscular mycorrhizae in soil ${ }^{9}$ as well as soil organic matter and soil structure $^{10}$, and soil particles through water and wind erosion. 
Cover crops, specifically winter rye (Secale cereale L.), for weed control in temperate regions have gained considerable popularity recently ${ }^{11}$, partly due to the advent of roller-crimpers used to terminate their growth effectively in spring ${ }^{12-17}$. A winter rye cover crop has several attributes. First, it is extremely cold-hardy, which allows for reliable over-winter survival in north temperate regions, such as Minnesota, where winter air temperatures of $-20^{\circ} \mathrm{C}$ commonly occur. Second, seed costs for vigorous and well-adapted varieties are modest, as little as US $\$ 50 \mathrm{ha}^{-1}$. Third, the plant grows lushly in early spring and inhibits weed seed germination and/or weed seedling establishment. Fourth, winter rye can be killed by mechanical means relatively easily at or just after anthesis. If done properly, the kill rate is nearly $100 \%$ and, thus, little resprouting or retillering occurs. Fifth, some summer crops, such as soybean, are relatively insensitive to leachates from decomposing winter rye residues, which may be inhibitory to other species, and fix their own nitrogen, which overcomes nitrogen immobilization caused by lushly growing rye. Sixth, winter rye cover crops have positive environmental characteristics, including sequestration of carbon and many labile soil nutrients, as well as inhibition of soil erosion.

Cover crops also have disadvantages. The major drawback of using winter rye as a cover crop is that its growth termination by mechanical methods must be delayed until anthesis. Anthesis usually does not occur until early to mid June in Minnesota, which means that relatively short-season soybean varieties $(<1.0 \mathrm{RM}$, relative maturity) with inherently lower yield potentials, must be planted in rye mulch. Traditional planting dates without cover crops for full-season soybean $(\geqslant 1.0 \mathrm{RM})$ in this region are early to mid May. Moreover, regardless of the late planting date, rolled and crimped rye mulch by itself may impose a yield penalty on soybean, either directly or through reduced stand establishment. At lower latitudes $\left(\leqslant 43^{\circ} \mathrm{N}\right)$ such as southern Wisconsin, central Illinois and central Pennsylvania, these penalties range from nil to about $20 \%$ of soybean yield ${ }^{12,13,15,18}$. In North Carolina, yield penalties across five site-years were $0,4,5$, 19 and $57 \%{ }^{17}$, with the latter value likely due to failure of the rye mulch to control weeds rather than a direct effect of rye mulch on soybean. In contrast, where growing seasons are longer, such as in Alabama, rolled and crimped winter rye mulches may provide yield rewards for soybean compared with conventional plantings ${ }^{16}$. How soybean responds to rolled and crimped rye mulches in the extremely short growing seasons of the northern Great Plains $\left(\geqslant 45^{\circ} \mathrm{N}\right)$ is not known.

Objectives of the current project were to compare stale seedbeds with roller-crimper terminated winter rye cover crops with regard to (i) pre- and post-plant weed seedling dynamics and end-of-season weed biomass, (ii) handweeding labor requirements, (iii) soybean stands and yields, and (iv) cursory calculations of economic returns for a north temperate region such as west central
Minnesota. The null hypothesis is that the aforementioned variables do not differ between stale seedbed and cover crop systems; whereas the alternative hypothesis is that a rye cover crop suppresses weeds so effectively that it may be a superior method compared with the stale seedbed approach.

\section{Materials and Methods}

\section{Field site}

Two identical experiments were performed at the Swan Lake Research Farm, Stevens County, MN (45 $41^{\prime} \mathrm{N}$, $\left.95^{\circ} 48^{\prime} \mathrm{W}\right)$ in 2010 and 2011. Separate fields, less than $100 \mathrm{~m}$ apart, were used each year. Soil type was a Barnes loam (fine-silty, mixed, super-active, frigid Calcic Hapludoll) with a $\mathrm{pH}$ of 7.3 , and sand, silt, clay and organic matter contents of about 41,33, 25 and $6 \%$, respectively. Camelina (Camelina sativa [L.] Crantz) was the previous crop in 2009 and soybean (Glycine $\max$ [L.] Merr.) in 2010.

\section{Experimental design and winter rye management}

Each experiment followed a randomized split plot design ${ }^{19}$ with four replications. Main plots comprised stale seedbed versus rye mulch treatments, and split plots involved intense or lax weed control, as detailed below.

For every experiment, a section of a field was partitioned into eight plots arranged in four blocks. Each plot was $6 \mathrm{~m}$ wide and $12 \mathrm{~m}$ long. One plot in each block was sown to winter rye ('FS Hi-Rye 500 ' on September 2, 2009 and September 20, 2010) at $73 \mathrm{~kg} \mathrm{ha}^{-1}$ in rows spaced at $20 \mathrm{~cm}$. These plots constituted the 'rye mulch' treatment. The remaining plots were fieldcultivated and fallowed over winter. These represented the 'stale seedbed' treatment. The entire area was fertilized with $112 \mathrm{~kg} \mathrm{Nha}^{-1}$ in the form of ammonium nitrate, which was incorporated with a field cultivator, immediately prior to sowing rye to eliminate $\mathrm{N}$ nutrition as a source of variation.

Heights of representative winter rye plants were measured at four random locations in each block at weekly intervals beginning in early May. Winter rye biomass was estimated by clipping all plants at ground level in two randomly placed $0.5 \mathrm{~m}^{2}$ quadrats in each block at the time that growth was terminated (June 9, 2010 and June 14, 2011). Samples were weighed immediately to determine fresh weight and then dried for one week at $50^{\circ} \mathrm{C}$ to determine dry weight. At the time of sampling, plants were in the post-anthesis stage, which was about 1 week after they had reached their maximum heights. Anthers extruded from flowers were dry and shriveled, which indicated that pollination was complete, and represented a useful rule-of-thumb for the time to terminate 
growth of a winter rye cover crop in west-central Minnesota.

Weed emergence patterns before planting soybean were recorded in one randomly placed but permanent quadrat (each $0.5 \mathrm{~m}^{2}$ ) in each plot of both the rye mulch and stale seedbed treatments. Seedlings were identified, counted, and removed by hand at approximately weekly intervals beginning in early May in both years.

Winter rye growth was terminated with a $3-\mathrm{m}$ wide, water-filled, roller-crimper with chevron-like blades ${ }^{13,20}$. Rolling-crimping occurred in a single direction parallel with the rows. Preliminary rolling-crimping in border plots indicated that winter rye lodging increased with tractor speed; consequently, all winter rye cover blocks were rolled and crimped at a speed of $\geqslant 10 \mathrm{~km} \mathrm{~h}^{-1}$. Rolling-crimping was highly effective in killing winter rye, with negligible regrowth observed.

\section{Soybean planting and management}

Soil in stale seedbed treatments was field-cultivated again and harrowed on the same dates as rolling-crimping. Such late seedbed preparation would have been expected to control large percentages of annual weeds at this site. In this region $>90 \%$ of potential seedling populations of common annual weeds typically can be controlled by seedbed preparation in early to mid June compared with more traditional seedbed preparation times in late April to early $\mathrm{May}^{8}$. Within 1 day after roller-crimping or field-cultivation, soybean was sown with a John Deere MaxEmerge no-till planter at 387,000 seeds ha ${ }^{-1}$ in rows spaced $76 \mathrm{~cm}$ apart. (The use of trade names does not imply product endorsement by USDA.) For comparison, target planting dates for conventional soybean (1.0 RM) are early to mid May in this area.

Both short- and nearly full-season varieties were tested each year. The short- and full-season soybeans were planted in contiguous but separate and non-randomized plots, and therefore, they were treated as separate experiments. The short-season variety was Croplan RT0043 (0.04 RM) both years; and the full-season variety was NK S08 M8 (0.8 RM) in 2010 and Croplan $970(0.9 \mathrm{RM})$ in 2011. The plots were $12 \mathrm{~m}$ long and $6 \mathrm{~m}$ wide (8 rows), and within each a 4-row subplot was assigned randomly to either of two weed management treatments: lax (little or no additional weed control) or intense (augmented weed control). For augmented weed control in stale seedbed plots, ethalfluralin was applied at $0.6 \mathrm{kgaiha}^{-1}$ and incorporated with a spring tine harrow. In addition, inter-row areas of all stale seedbed plots were cultivated once in mid July. Hand-weeding supplemented the herbicide-treated and cultivated stale seedbed subplots, and it was the sole form of additional weed control in the augmented rye mulch plots. Hand-weeding included both hand-pulling and hoeing with long-handled hoes. Amounts of time spent hand-weeding were recorded. Decisions of whether or not to hand-weed a plot were made by two technicians with about 40 years of combined experience in research on soybean-weed interactions. Decisions were subjective and were meant to mimic those of hand-laborers hired by growers.

In summary, each soybean experiment had the following treatments: (1) stale seedbed (stale seedbed augmented by inter-row cultivation), (2) stale seedbed plus (stale seedbed augmented with ethalfluralin, cultivation, and hand-weeding), (3) rye mulch (winter rye mulch only), and (4) rye mulch plus (winter rye mulch augmented by hand-weeding).

\section{Weed monitoring}

Weed emergence patterns after planting were estimated by permanently and randomly positioning two $0.5 \mathrm{~m}^{2}$ quadrats in each augmented subplot of the short-season soybean only, and identifying, counting, and removing all weed seedlings at approximately weekly intervals beginning immediately after soybean planting and continuing through September. Quadrats were lifted and replaced immediately before and after inter-row cultivation events in the stale seedbed plots. Weed biomass was determined on September 22, 2010 and September 28, 2011 by clipping all weeds at ground level within a $0.5 \mathrm{~m}^{2}$ quadrat $(0.5 \times 1.0 \mathrm{~m})$ that was perpendicular to and spanned the central two soybean rows in each subplot of the shortseason soybean.

Soybean yield was determined by harvesting the central two rows of short- and full-season soybean in each subplot with a plot combine on October 6 and 12, 2010 (prior to the first killing frost of autumn) and October 4 and 7, 2011 (after the first killing frost on September 14). Seed yield samples were cleaned of chaff and other debris, seed moisture determined (via a capacitance meter), weighed, sample weights adjusted to $13 \%$ seed moisture and unitarea yields calculated. Soybean stand was determined by counting cut stems in two 1-m lengths of row in each subplot immediately after harvest.

\section{Statistical evaluations}

Statistical evaluations included preliminary analysis of variance (ANOVA) that considered the soybean establishment method (rye mulch versus stale seedbed) and weed management (intense versus lax) as fixed effects and block (four replications) and year (2010 and 2011) as random effects. Year effects were always highly significant $(P<0.01)$ and, consequently, yearly data were examined separately using the split plot procedure available in Statistix 9 software ${ }^{19}$, with the establishment method as the main factor and weed management as the sub factor. Tukey's HSD was used to compare treatment means at $P=0.05$ or 0.10 . Lastly, linear regression was used to explore the relationship between soybean stand density and soybean yield. 

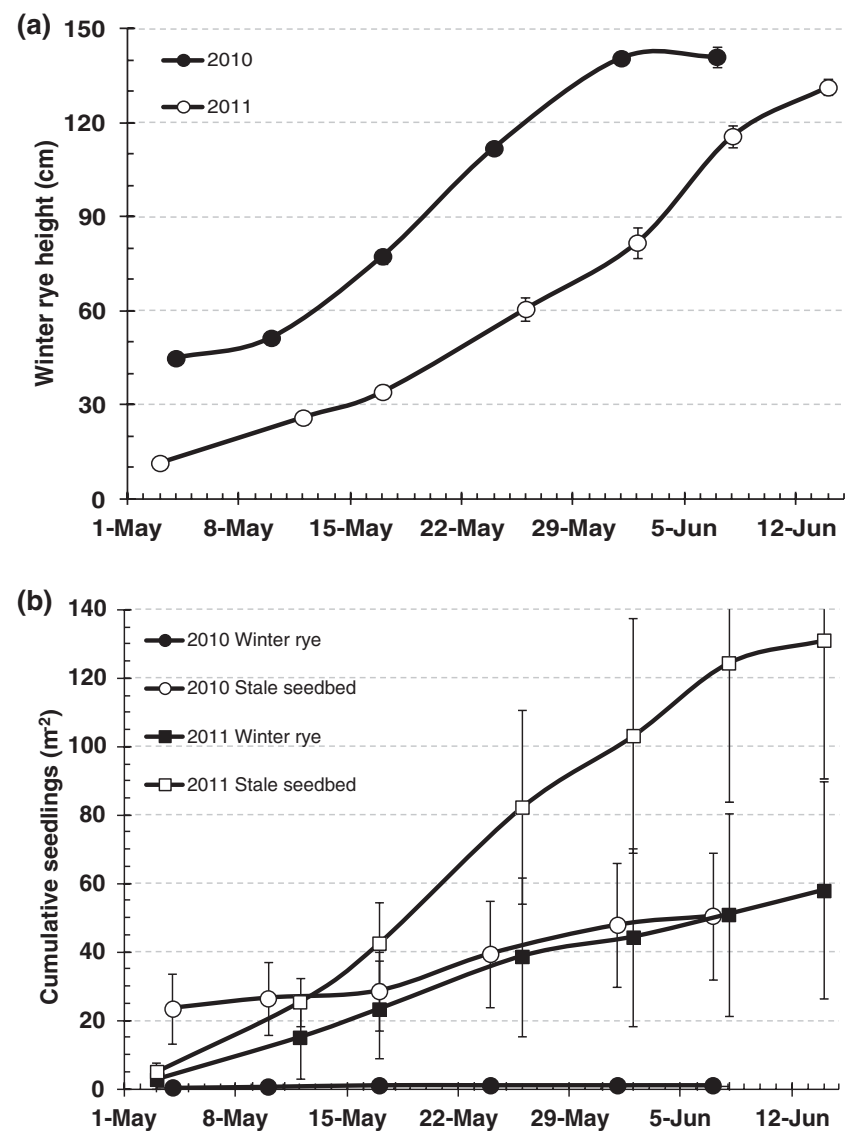

Figure 1. (a) Increase in height of winter rye during May and June 2010 and 2011, with growth terminated by rolling and crimping on June 9, 2010 and June 14, 2011. (b) Cumulative emergence of weed seedlings prior to soybean planting in a winter rye cover crop and a stale seedbed during spring of 2010 and 2011. Vertical bars represent standard errors.

\section{Results}

\section{Winter rye growth}

Winter rye growth (Fig. 1a) probably was delayed in spring 2011 compared with 2010 because of the late snow-melt and abnormally low temperatures. Although winter rye grew rapidly during May each year, the cover crop was more vigorous in 2010 than 2011. Height, fresh weight, and dry weight $( \pm \mathrm{SE})$ of winter rye at termination with a roller-crimper on June 11, 2010 were $141 \pm 3.3 \mathrm{~cm}, 26 \pm 3.6 \mathrm{Mgha}^{-1}$ and $6.0 \pm 1.04 \mathrm{Mg} \mathrm{ha}^{-1}$; and on June 14, 2011 these same variables were $131 \pm 2.6 \mathrm{~cm}, 22 \pm 3.9 \mathrm{Mgha}^{-1}$ and $6.0 \pm 0.89 \mathrm{Mgha}^{-1}$. The rolled and crimped winter rye created mulch on the soil surface that was $5-15 \mathrm{~cm}$ thick.

For comparison, dry weights of 'Hi-Rye' at the time of rolling-crimping were 6-7 $\mathrm{Mgha}^{-1}$ (mid May) in central Illinois $^{13}$; 'Rymin' winter rye was nearly $11 \mathrm{Mgha}^{-1}$ (early June) in southern Wisconsin ${ }^{12}$ and $4.5-11 \mathrm{Mgha}^{-1}$ (May) in North Carolina ${ }^{17}$; and 'Aroostock' winter rye ranged from about 6 to $10 \mathrm{Mgha}^{-1}$ (early June) in central Pennsylvania ${ }^{15}$.

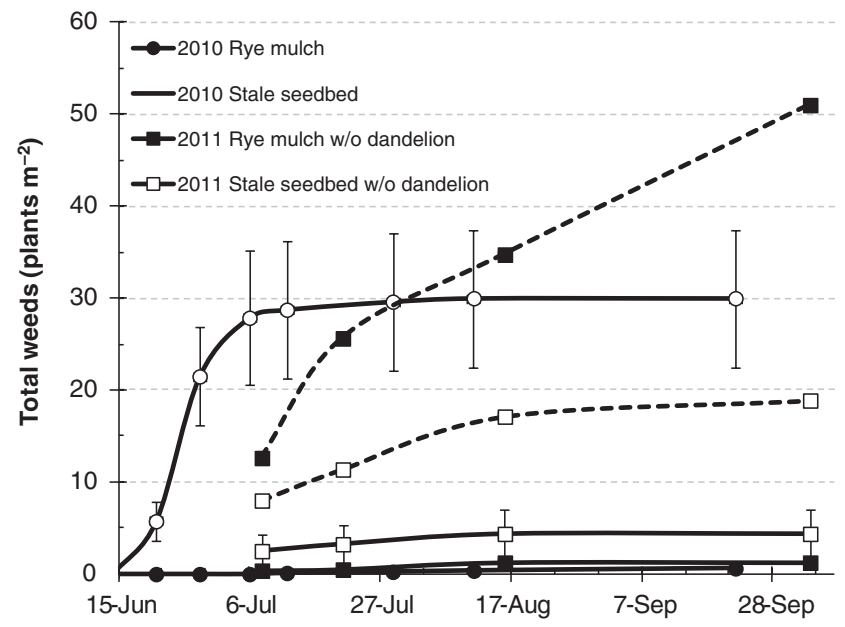

Figure 2. Cumulative emergence of all weed seedlings combined after soybean planting in winter rye mulches and stale seedbeds during summers of 2010 and 2011. In 2011, solid lines represent combined annual weeds without the perennial, dandelion, whereas the dotted lines include dandelion (77 and $98 \%$ of recorded plants in stale seedbed and rye mulch, respectively). Vertical bars represent standard errors. (For clarity, SE not included for 2011 values with dandelion.)

\section{Weed emergence, biomass and hand-weeding}

Pre-plant weed emergence was curtailed appreciably by the presence of growing winter rye (Fig. 1b). In 2010, cumulative total emergence of all weed species combined was $51 \pm 18.5$ plants $^{-2}$ in the stale seedbed system, but only $1 \pm 0.3$ plants $\mathrm{m}^{-2}$ in rye mulch. Analogous values in 2011 were $131 \pm 40.5$ plants $^{-2}$ in the stale seedbed and $58 \pm 31.7$ plants $^{-2}$ in rye mulch. Thus, winter rye provided $98 \%$ pre-plant weed control in 2010 and $56 \%$ in 2011 in terms of seedling numbers. Observations indicated that plant sizes also decreased substantially by the presence of rye mulch. The dominant weed species were eastern black nightshade (Solanum ptycanthum Dun.) in 2010 and redroot pigweed (Amaranthus retroflexus L.) in 2011. Nightshade and pigweed represented 60 and $12 \%$ of the total pre-plant weed population of the stale seedbed system in 2010 and 4 and 50\% in 2011. The presence of rye mulch decreased pre-plant densities of these two species by $\geqslant 82 \%$. Nightshade control is especially critical in organic systems in terms of nightshade berry and seed contamination and pigment staining of soybean seed at harvest.

Post-plant weed emergence patterns were affected by the presence of rye mulch, but in contrasting manners during the 2 years (Fig. 2). In 2010, about $30 \pm 7.5$ plants $^{-2}$ emerged in the stale seedbed system compared with only $1 \pm 0.3$ plants $\mathrm{m}^{-2}$ in rye mulch. Emergence was complete by mid July. Half of the plants in the stale seedbed system comprised annual weeds common to the research farm: nightshade, pigweed, common lambsquarters (Chenopodium album L.) and foxtails (Setaria spp.). The remaining plants were dandelion (Taraxacum officinale 
Weber). Pigweed and dandelion evenly represented the few plants that emerged in rye mulch.

The pattern of emergence in 2011 began later and continued longer than in 2010 and, surprisingly, densities were higher in the rye mulch than in the stale seedbed system (Fig. 2). The stale seedbed system supported $19 \pm 8.2$ plants $^{-2}$ whereas $51 \pm 46.4$ plants $^{-2}$ emerged in the winter rye mulch. About $23 \%$ of the plants in the stale seedbed system were pigweed, lambsquarters and foxtail and the rest were dandelion. In contrast, $97 \%$ of the plants in the rye mulch were dandelion, the rest being an even mixture of foxtail, lambsquarters, nightshade and pigweed. The early growing season (May through July) of 2011 was moist ( $315 \mathrm{~mm}$ rain) compared with that of 2010 (182 $\mathrm{mm}$ rain), which allowed dandelion to reproduce vigorously over spring and summer throughout the general area. The rye mulch probably trapped many wind-blown dandelion seeds, which lack dormancy ${ }^{21}$, during that time and created an excellent seedbed for them to germinate immediately. Excluding dandelion from the calculations, then post-plant annual weed emergence was $4.4 \pm 2.61$ and $1.3 \pm 0.66 \mathrm{~m}^{-2}$ in the stale seedbed and rye mulch treatments, respectively (Fig. 2), which proportionally reflects the results in 2010 .

Weed biomass (dry weight) at the end of the 2010 growing season was influenced substantially by the establishment method (main factor, $P=0.04$ ), weed management (sub factor, $P=0.01$ ) and interactions between these two variables $(P=0.01)$. Total weed biomasses in stale seedbed, stale seedbed plus, rye mulch and rye mulch plus treatments were $453 \pm 131.3,8 \pm 5.6,1 \pm 1.0$ and $1 \pm 0.5 \mathrm{~g} \mathrm{~m}^{-2}$, respectively (Tukey's $\mathrm{HSD}_{0.05}=308$ ). In contrast, at the end of the 2011 growing season, weed biomass was not influenced by the establishment method $(P=0.48)$, weed management $(P=0.94)$ or interactions $(P=0.72)$, primarily because of the high levels of dandelion that proliferated in the rye mulch plots during late summer. Nevertheless, weed biomass averaged only $35 \pm 8.7 \mathrm{~g} \mathrm{~m}^{-2}$ across treatments in 2011 , which probably was not high enough to have interfered with soybean growth and yield in any treatment.

For comparison, in Illinois total end-of-season weed biomass in soybean was reduced from about $500 \mathrm{~g} \mathrm{~m}^{-2}$ in stale seedbeds to $<100 \mathrm{~g} \mathrm{~m}^{-2}$ in rye mulch ${ }^{13}$. In southern Wisconsin, weed biomass in early July was reduced by $62 \%$ in rye mulch compared with stale seedbeds ${ }^{12}$. In central Pennsylvania, mid-summer weed biomass reduction in soybean due to rolled and crimped winter rye compared with bare soil across five site-years was 15, 53, 91, 92 and $93 \%{ }^{18}$. Lastly, in the absence of herbicides, rolled and crimped rye in Alabama provided 58, 69 and $83 \%$ weed control over 3 years ${ }^{16}$.

\section{Hand-weeding}

Four hand-weedings were performed in 2010 (June 29 and July 8, 19 and 29) in the stale seedbed system that was augmented with herbicide. Cumulative times (laborhours) were equivalent to $66 \pm 9.2 \mathrm{~h} \mathrm{ha}^{-1}$ in the shortseason soybean and a nearly identical duration of $61 \pm 8.3 \mathrm{hha}^{-1}$ in the full-season soybean. No handweeding was needed in the rye mulch system because of the paucity of weeds. Two hand-weeding efforts were conducted in 2011 (July 25 and August 17). Cumulative labor-hours were $15 \pm 6.6$ and $22 \pm 4.9 \mathrm{~h} \mathrm{ha}^{-1}$ in the stale seedbed short- and full-season soybeans, which also received herbicide, but only $3 \pm 0.2$ and $6 \pm 1.9 \mathrm{hha}^{-1}$ were needed in the rye mulch short- and full-season soybean treatments, which were herbicide-free. Thus, the rye mulch either eliminated or greatly reduced labor requirements for hand-weeding.

For comparison, an average hand-weeding time of $5 \mathrm{hha}^{-1}$ was reported for high-value organic soybean (sans cover crop) in Iowa ${ }^{22}$, but this was only for removing weeds that overtopped the crop later in the growing season. In Ontario, Canada, hand-weeding (at $\$ 10 \mathrm{~h}^{-1}$ ) was the major expense for organic weed management, where costs ranged from $\$ 92$ to $\$ 288 \mathrm{ha}^{-1}$, which represents about $8-25 \mathrm{~h} \mathrm{ha}^{-1}$ of labor ${ }^{23}$. Hand-weeding in high-value vegetable crops may require up to $175 \mathrm{~h} \mathrm{ha}^{-1}$ in New York State ${ }^{24}$ and $>200 \mathrm{~h} \mathrm{ha}^{-1}$ in California ${ }^{25}$. The latter statistic is only for 'hand-weeding' literally (i.e., hand pulling), as hand-hoeing is considered a different class of manual labor in California.

\section{Soybean stand}

Stand densities differed between years for both shortseason $(P=0.07)$ and full-season $(P<0.01)$ soybean, and there were year $\times$ establishment method interactions for both varieties $(P=0.05,0.03)$. Consequently, stands for both varieties were analyzed separately each year. In 2010, short-season soybean stands were influenced by the establishment method $(P=0.05)$, but not weed management $(P=0.23)$ nor an establishment method $\times$ weed management interaction $(P=0.17)$. Stands averaged $335,000 \pm 16,000$ plants ha $^{-1}$ in the stale seedbed system and $266,000 \pm 15,000$ plantsha $^{-1}$ in the rye mulch system (Tukey's HSD H.10 $=53,000$ ). In 2011, no variable or interaction influenced short-season soybean stands $(P>0.68)$. Stand density averaged $333,000 \pm 11,000$ plants $\mathrm{ha}^{-1}$ across treatments.

In 2010, full-season soybean stands were not influenced by the establishment method $(P=0.23)$ nor weed management $(P=0.83)$, but an interaction did exist $(P=0.06)$. Densities in stale seedbed, stale seedbed plus, rye-mulch and rye-mulch plus treatments were $291,000 \pm 18,000, \quad 263,000 \pm 18,000, \quad 214,000 \pm 28,000$, and $237,000 \pm 30,000$ plants ha $^{-1}$, respectively (Tukey's $\mathrm{HSD}_{0.10}=44,000$ between establishment methods). In 2011, full-season soybean stands were affected by the establishment method $(P=0.08)$, but not weed management $(P=0.77)$ nor an interaction $(P=0.49)$. In this instance, rye mulch plots had higher densities 
$\left(340,000 \pm 18,000\right.$ plants ha $\left.^{-1}\right)$ than stale seedbed plots $\left(312,000 \pm 15,000\right.$ plants ha $\left.^{-1}\right)$.

In summary, treatment effects were inconsistent regarding soybean stands. The year effect probably was due to poor soil-seed contact in 2010, which was caused by incomplete closure of the soil slot created by the planter's double-disk openers. Failure of the packing wheel to close the slot was a result of wet soil conditions at planting, generally, and root-bound soil, specifically, in the rye mulch plots. Root-bound soil on the sidewalls of the slot tended not to crumble and overtop seeds, and dry weather immediately after planting inhibited exposed seeds from germinating. In 2011, the packing wheel was adjusted to facilitate better closure of the seeding slot, and plentiful rainfall after planting assured high germination rates and good stand establishment. For comparison, soybean stands in southern Wisconsin, central Pennsylvania, and North Carolina either were not affected or were influenced inconsistently by rye mulch ${ }^{12,15,17}$.

\section{Soybean yield}

Yields differed between years for both short-season $(P<0.01)$ and full-season $(P<0.01)$ soybean, and there were year $\times$ establishment method interactions for both varieties $(P=0.03$ and 0.05$)$. Consequently, yields for both varieties were analyzed separately each year. Shortseason soybean yields in 2010 were influenced by the establishment method $(P=0.09)$, but not by weed management $(P=0.61)$ nor an establishment method $\times$ weed management interaction $(P=0.34)$. Yields averaged $2560 \pm 220 \mathrm{kgha}^{-1}$ in the stale seedbed system and $1770 \pm 120 \mathrm{kgha}^{-1}$ in the rye mulch system (Tukey's $\left.\mathrm{HSD}_{0.10}=740\right)$. In 2011, no variable or interaction influenced short-season soybean yields $(P \geqslant 0.72)$, which averaged $1360 \pm 100 \mathrm{~kg} \mathrm{ha}^{-1}$

Full-season soybean yields in 2010 were affected by the establishment method $(P<0.01)$, weed management $(P=0.08)$ and an establishment method $\times$ weed management interaction $(P<0.01)$. In the stale seedbed, stale seedbed plus, rye mulch and rye mulch plus treatments, full-season soybean yields averaged $2640 \pm 190,3260 \pm 120$, $2080 \pm 110$ and $1830 \pm 110 \mathrm{~kg} \mathrm{ha}^{-1}$, respectively (Tukey's $\left.\mathrm{HSD}_{0.05}=420\right)$. In 2011, no variable or interaction influenced full-season soybean yields $(P \geqslant 0.12)$, which averaged $1960 \pm 120 \mathrm{~kg} \mathrm{ha}^{-1}$.

For comparison, in Illinois weed-free soybean (3.0 RM) attained yields of $2200-3200 \mathrm{kgha}^{-1}$ in rye mulch compared with $2700-3800 \mathrm{kgha}^{-1}$ in bare soil, with locally late planting dates of May 24 to June $2^{13}$. Similarly, in Wisconsin soybean $(1.0 \mathrm{RM})$ yields were about $2800 \mathrm{~kg} \mathrm{ha}^{-1}$ in rye mulch and $3600 \mathrm{~kg} \mathrm{ha}^{-1}$ in stale seedbeds planted late (May 18-June 17) ${ }^{12}$. Thus, mulch derived from rolled and crimped winter rye lowered yield potential more in 2010 in Minnesota (31-34\%) than in Illinois and Wisconsin (16-22\%). This geographical difference probably reflects the shorter growing season and greater aridity of western Minnesota compared with Illinois and Wisconsin. Furthermore, negative effects of rye at these locations on soybean yield would be exacerbated by late soybean planting and soil water use by winter rye.

The linear regression relationship between soybean yield and soybean stand was significant in 2010 for both short-season $(F=10.8, P=0.01)$ and full-season varieties $(F=5.5, P=0.03)$. However, the intensity of the relationships was modest with low $r^{2}$ values $(0.43$ and 0.27$)$ and slopes of only 7 and $6 \mathrm{~kg}$ seed yield $1000^{-1}$ plants, respectively. Yield and stand were not related in 2011; corresponding statistics for short- and full-season varieties were $F=0.7,0.1 ; P=0.41,0.71 ; r^{2}=0.05,0.01$; and slopes of 2 and $1 \mathrm{~kg}$ seed yield $1000^{-1}$ plants.

In summary, the generally lower yields in 2011 compared with 2010 probably were caused by 2011's early frost (September 14), which terminated seed maturation of both varieties prematurely. A comparably low temperature in 2010 was not reached until October 15, which was after soybean harvest. As a consequence, soybeans were able to reach their yield potentials in 2010. Similarly, the longer growing season in 2010 allowed expression of effects of the establishment method, specifically the effects of a stale seedbed (dense stands and high yields) compared with rye mulch (poorer stands and lower yields). Rye mulch sufficiently impeded weed emergence and growth that even in the weedy treatment soybean yield losses due to weed competition were not detected. In contrast, stale seedbeds without augmented weed control could have weed populations high enough to make an appreciable impact on soybean yield. Lastly, no management effects were apparent during a year with an abruptly terminated (early frost) growing season, as in 2011.

\section{Conclusions}

Both pre-plant and post-plant populations of common annual weeds were lowered appreciably by the use of winter rye mulches compared with stale seedbeds. As a consequence hand-weeding requirements were negligible $\left(0-6 \mathrm{hha}^{-1}\right)$ in soybean planted into rye mulch, but ranged from 15 to $66 \mathrm{hha}^{-1}$ in stale seedbed systems. Thus, rye mulches can clearly lower hand-weeding efforts, but rye mulches also have the capacity to lower yield potential of both short- and full-season soybean, for instance by 31 and $34 \%$, respectively, in 2010, compared with the use of stale seedbeds. These yield decreases translate into losses of about $800-1000 \mathrm{~kg} \mathrm{ha}^{-1}$ of soybean seed with the use of rye mulches. Market values of feed grade soybean seeds were $\$ 0.53 \mathrm{~kg}^{-1}$ (conventional) and $\$ 1.04 \mathrm{~kg}^{-1}$ (organic) in mid May 2012. Thus, with winter rye as a cover crop, gross returns for soybean could be lowered by about $\$ 500 \mathrm{ha}^{-1}$ for conventional soybean and $\$ 1000 \mathrm{ha}^{-1}$ for organic soybean compared with soybean planted into stale seedbeds without rye mulch. 
The use of stale seedbeds, however, potentially entails higher management costs for weed control compared with the use of winter rye cover crops. For example, in 2010 full-season soybean yield was lowered by nearly $900 \mathrm{~kg} \mathrm{ha}^{-1}$ because of weeds not controlled by inter-row cultivation in the stale seedbed system. This reduction represents gross return losses of about $\$ 450 \mathrm{ha}^{-1}$ (conventional) to $\$ 900 \mathrm{ha}^{-1}$ (organic), which are comparable with the penalties imposed by the use of winter rye cover crops (see previous paragraph). If $60 \mathrm{~h}$ of hand labor were required to remove the offending weeds, as in 2010, and labor was valued at $\$ 10 \mathrm{~h}^{-1}$, then this input would be worth $\$ 600 \mathrm{ha}^{-1}$. Thus, hand labor may still be a rational option for organic soybean planted in stale seedbeds (i.e., $\$ 900-\$ 600=\$ 300$ net gain), but less likely so for conventional soybean (i.e., $\$ 450-\$ 600=\$ 150$ net loss). These admittedly coarse calculations also suggest that a conventional grower in Minnesota with herbicide resistance problems would benefit more from adopting winter rye cover crops than the stale seedbed technique to manage resistant annual weeds. In contrast, the stale seedbed technique augmented by hand-weeding compared with winter rye cover crops probably is roughly equally cost-effective for organic growers in Minnesota, assuming labor for hand-weeding is available when needed. In the absence of assured availability of sufficient hand labor, the value of winter rye cover crops increases markedly.

Acknowledgements. This project would not have been possible without the assistance and dedication of Dean Peterson, James Eklund, Charles Hennen and Scott Larson.

\section{References}

1 Powles, S.B. and Yu, Q. 2010. Evolution in action: plants resistant to herbicides. Annual Review of Plant Biology 61:317-347.

2 Moynihan, M. 2010. Status of Organic Agriculture in Minnesota. Minnesota Department of Agriculture, St. Paul, MN, p. 55. Available at Web site http://www. mda.state.mn.us/ /media/Files/news/govrelations/organicstatusreport.ashx (verified October 17, 2012).

3 Walz, E. 2004. Fourth National Organic Farmers' Survey. Organic Farming Research Foundation, Santa Cruz, CA, p. 106. Available at Web site http://www.agmrc.org/media/ cms/organicsurveyresults_6F6C9F2840CF6.pdf (verified October 17, 2012).

4 Bond, W. and Grundy, A.C. 2001. Non-chemical weed management in organic farming systems. Weed Research 41:383-405.

5 Melander, B., Rasmussen, I.A., and Barberi, P. 2005. Integrating physical and cultural methods of weed control examples from European research. Weed Science 53: 369-381.

6 Johnson, W.C. and Mullinix, B.G. 1998. Stale seedbed weed control in cucumber. Weed Science 46:698-702.
7 Coulter, J.A., Sheaffer, C.C., Haar, M.J., Wyse, D.L., and Orf, J.F. 2011. Soybean cultivar response to planting date and seeding rate under organic management. Agronomy Journal 103:1223-1229.

8 Forcella, F., Eradat-Oskoui, K., and Wagner, S.W. 1992. Application of weed seedbank ecology to low-input crop management. Ecological Applications 3:74-83.

9 Douds, D.D, Nagahashi, G., and Shenk, J.E. 2012. Frequent cultivation prior to planting to prevent weed competition results in an opportunity for the use of arbuscular mycorrhizal fungus inoculum. Renewable Agriculture and Food Systems 27:251-255.

10 Reicosky, D.C., Kemper, W.D., Langdale, G.W., Douglas, C.L., and Rasmussen, P.E. 1995. Soil organic matter changes resulting from tillage and biomass production. Journal of Soil and Water Conservation 50:253-261.

11 Brennan, E.B. and Boyd, N.S. 2012. Winter cover crop seeding rate and variety effects during eight years of organic vegetables: I. Cover crop biomass production. Agronomy Journal 104:684-698.

12 Bernstein, E.R., Posner, J.L., Stoltenberg, D.E., and Hedtcke, J.L. 2011. Organically managed no-tillage ryesoybean systems: agronomic, economic, and environmental assessment. Agronomy Journal 103:1169-1179.

13 Davis, A. 2010. Cover-crop roller-crimper contributes to weed management in no-till soybean. Weed Science 58:300-309.

14 Kornecki, T.S., Price, A.J., and Raper, R.L. 2006. Performance of different roller designs in terminating rye cover crop and reducing vibration. Applied Engineering in Agriculture 22:633-641.

15 Nord, E.A., Curran, W.S., Mortensen, D.A., Mirsky, S.B., and Jones, B.P. 2011. Integrating multiple tactics for managing weeds in high residue no-till soybean. Agronomy Journal 103:1542-1551.

16 Price, A.J., Reeves, D.W., and Patterson, M.G. 2006. Evaluation of three winter cereals for weed control in conservation-tillage non-transgenic soybean. Renewable Agriculture and Food Systems 21:159-164.

17 Smith, A.N., Reberg-Horton, S.C., Place, G.T., Meijer, A.D., Arellano, C., and Mueller, J.P. 2011. Rolled rye mulch for weed suppression in organic no-tillage systems. Weed Science 59:224-231.

18 Mischler, R.A., Curran, W.S., Duiker, S.W., and Hyde, J.A. 2010. Use of a rolled-rye cover crop for weed suppression in no-till soybeans. Weed Technology 24:353-261.

19 Anonymous. 2008. Statistix 9 User's Manual. Analytical Software, Tallahassee, FL. p. 454.

20 Mirsky, S., Curran, W.S., Mortensen, D., Ryan, M., and Shumway, D. 2009. Control of cereal rye with a rollercrimper as influenced by cover crop phenology. Agronomy Journal 101:1589-1596.

21 Martinkova, Z., Honek, A., and Lukas, J. 2011. Viability of Taraxacum officinale seeds after anthesis. Weed Research 51:508-515.

22 Delate, K. 2002. Using an agroecological approach to farming systems research. HortTechnology 12:345-354.

23 Anonymous. 2008. Pesticide risk reduction for soybean production. Final Research Report E2008-36. Organic Agriculture Centre of Canada. Available at Web site http:// www.organicagcentre.ca/Docs/TechnicalBulletins08/ TechnicalBulletin36web_risk.pdf (verified October 17, 2012). 
24 Evans, G.J., Bellinder, R.R., and Hahn, R.R. 2011. Integration of vinegar for in-row weed control in transplanted bell pepper and broccoli. Weed Technology 25:259-265.

25 Gianessi, L. and Reigner, N. 2006. Barriers to widespread conversion from chemical pest control to non-chemical methods in U.S. agriculture. In Proceedings of the Third International Conference on the Future of Agriculture, Sacramento, California. Available at Web site http://www. engg.ksu.edu/chsr/events/ag/200608/. (verified October 17, 2012). 